\title{
Stabilization of acid-alkaline balance of weakly acidic soils under biologization of sugar beet cultivation in conditions of Forest-Steppe of Ukraine
}

Zaryshniak A. ${ }^{1}$, Sypko A. ${ }^{2}$, Strilets $\mathrm{O}^{3}$, Zatcerkovna N. ${ }^{4}$, Zinchenko $0 .{ }^{5}$, Sinchuk $\mathrm{H}^{6}{ }^{6}$, Goncharuk $\mathrm{H}^{7}$ Grytsyshyna L. ${ }^{8}$, Kostashchuk M. ${ }^{9}$, Mazur H. ${ }^{10}$

1-6/nstitute of bioenergy crops and sugar beet of NAAS, Klinichna Str., 25, Kyiv, 03141, Ukraine, 7 , ${ }^{8}$ Yaltushky research-selection station of Institute of bioenergy crops and sugar beet of NAAS, $v$. Yaltushkiv, Bar District, Vinnytsia oblast, 23021, Ukraine, 9, ${ }^{10}$ Uladovo-Liulinetska research-selection station of Institute of bioenergy crops and sugar beet of NAAS, Uladivske, Kalynivka Region, Vinnytsia oblast, 22412, Ukraine; e-mail: 1-6sugarbeet@ukr.net, 7,8vmvdss@ukr.net, 9, ${ }^{10} u l d s s 1888 @ u k r . n e t$

The purpose. To determine optimum dozes and ways of use of defecate which provide stabilization of acid-alkaline balance of grey forest sub-acidic soil and leached sub-acidic chernozem at biologization of cultivation of sugar beet in conditions of Right-bank and Central Forest-Steppe of Ukraine. Methods. Physical-and-chemical, agrochemical analysis of soil and plants. Results. The most efficient for soilabsorbing complex of grey forest sub-acidic soil were 1,5 dose of $\mathrm{CaCO}_{3}$ on hydrolytic acidity $\left(\mathrm{CaCO}_{3}(9,0\right.$ t/hectare in physical weight) with the background of level-by-level entering of organic-mineral fertilizers. Thus it was achieved the maximal neutralization of acidity of soil: parameter $\mathrm{pH}_{\text {salt }}$ of soil solution has increased up to 7,2 , hydrolytic acidity of soil lowered to $0,42 \mathrm{mg}-\mathrm{eq} / \mathrm{kg}$ of soil with simultaneous increase of the sum of absorbed bases up to $25,7 \mathrm{mg}-\mathrm{eq} / \mathrm{kg}$ of soil and degree of saturation with bases to $95,3 \%$. At entering ameliorant under plowing on leached typical sub-acidic chernozem in 1,5 dose of $\mathrm{CaCO}_{3}$ ( $7,5 \mathrm{t} /$ hectare in physical weight) they fixed increase of pHsalt up to 6,9 , that corresponded to neutral degree of acidity of soil. At that dose of ameliorant hydrolytic acidity of soil dropped to $1,50 \mathrm{mg}-\mathrm{eq} / \mathrm{kg}$ of soil with simultaneous increase of the sum of absorbed bases up to $28,5 \mathrm{mg}-\mathrm{eq} / \mathrm{kg}$ of soil. Content of mobile links of calcium $(\mathrm{CaO})$ increased up to $175 \mathrm{mg}-\mathrm{eq} / \mathrm{kg}$ of soil with simultaneous increase of mobile magnesium (MgO) up to $24 \mathrm{mg}-\mathrm{eq} / \mathrm{kg}$ of soil. Conclusions. Use of defecate on sub-acidic grey forest soil and leached sub-acidic typical chernozem at biologization of cultivation of sugar beet promotes stabilization of acid-alkaline balance of soils.

Key words: biologization, soil, hydrolytic acidity, ameliorant, soil-absorbing complex, acid-alkaline balance.

DOI: https://doi.org/10.31073/agrovisnyk201903-03

Optimization of the system for controlling the productive and ecological functions of acid soils for various technologies of chemical amelioration by effective application of ameliorants for the biologization of fertilizer systems is an important step in stabilizing the acid-alkaline balance and the productivity of acid soils. The solving of these issues in modern agriculture is especially relevant for the regions of the distribution of acidic soils.

Prolonged application of mineral fertilizers in grain-sugar beet rotations acidizes the soil solution with a decrease in the amount of absorbed alkaline ions in the base-saturation complex. When increase the share of row-crops in rotation the acidification of the soil solution increases.

Earlier studies of domestic and foreign scientists have defined a significant effect of chemical amelioration of acid soils and by-products application on the restoration of fertility and productivity of agrochemically degraded soils [1-6].

To optimize the physical-chemical indicators of black soils in grain-sugar beet rotation, it is necessary to implement chemical amelioration through defecate application, with the norm calculated by hydrolytic acidity and applying it on the background of the organic-mineral system of fertilizers [7]. 
Stabilization of acid-alkaline balance in black soils is determined by the organic-mineral system of fertilizers in crop rotation under the decrease a share of row-crops and the doses of the fertilizers [8].

The biologization of modern agriculture should be aimed at a balanced biological cycle of biogenic elements, which involves all biological resources, in particular straw and of intermediate crops residues $[9,10]$.

Recently, as organic fertilizers in sugar beet crops, winter wheat straw is widely used by plowing its residues (4-6 t / ha) after harvesting with harvester. Wherein, 18-27 $\mathrm{kg}$ of nitrogen, 3,0-4,5 $\mathrm{kg}$ of phosphorus, $26-39 \mathrm{~kg}$ of potassium returns into the soil and the corresponding amount of micronutrients [11].

The marked increase in the acidity of the soil (by 0.1 units) under application of cereal straw and green mass of green manure was determined. This is due to the formation during their decomposition of organic acids and a very small amount of neutralizing cations - ammonia and calcium, which requires the application of chemical ameliorants [12].

The biologization of agriculture is greatly improved, agro-physical, physical-chemical and water properties of the soil. Fifteen-year application in grain-row crops rotation of by-products of field crops (5t / ha) and permanent cultivation of perennial grasses increased water resistance of soil aggregates, filtration and soil moisture absorption by soil [13].

Plowing into the soil of winter wheat straw, according to research data of recent years, can increase the yield of roots on 1.3-2.1 $\mathrm{t} / \mathrm{ha}$, sugar content - on $0.1-0.3 \%$, sugar harvest - on $0.14-0.22 \mathrm{t}$ /ha. Combined application of straw and fertilizers increases the yield of roots on 9.2-12.6 $\mathrm{t} /$ ha, sugar harvest - on 1.8-2.4 $\mathrm{t} / \mathrm{ha}[14]$.

The system of chemical amelioration of acidic soils enrich by biologization of agriculture will assure the stabilization of the acid-alkaline balance of weakly acidic soils with a decrease of nutrient load in agroecosystems.

Investigation purpose is to study the patterns of the influence of chemical amelioration technologies under biologization of sugar beet cultivation on stabilization of the acid-alkaline balance of gray forest weakly acidic and leached black soil in the conditions of the Right Bank and Central ForestSteppe of Ukraine.

Materials and investigation methods. The research was carried out in grain-row crop rotation during 2016-2018 at Yaltushkivska and Uladovo-Lulinetsky research-breading stations of the Right Bank and Central Forest-Steppe of Ukraine.

The soil of Yaltushky RBS is gray forest weakly acidic, having the following agrochemical indicators in $0-30 \mathrm{~cm}$ soil layer: humus content by Tyurin $-1.5 \%$, alkaline hydrolyzed nitrogen by Cornfield - 75.0-77.6 $\mathrm{mg} / \mathrm{kg}$ of soil, mobile phosphorus $\left(\mathrm{P}_{2} \mathrm{O}_{5}\right)$ and potassium $\left(\mathrm{K}_{2} \mathrm{O}\right)$ by Kirsanov - respectively 127-131 and 115-123 mg / kg of soil, pHsalt - 5,5, the hydrolytic acidity by Kappen - 2,5-2,9 mg-equiv. I $100 \mathrm{~g}$ of soil, the degree of bases saturation $-80-83 \%$.

The crop drilling area $-100 \mathrm{~m}^{2}$, the accounting area $-50 \mathrm{~m}^{2}$, the repetition is four times. Threeyear old defecate applied layer-by-layer over the background of organic-mineral fertilizers determined by the hydrolytic acidity index of the soil in accordance with the experimental scheme. Defecate contained: $\mathrm{CaCO}_{3}$ - up to $75 \%$, organic matter $-12 \%$, nitrogen $-0.3-0.5 \%$, phosphorus $\left(\mathrm{P}_{2} \mathrm{O}_{5}\right)-0.2-0.4 \%$, potassium $\left(\mathrm{K}_{2} \mathrm{O}\right)-0.2-0,3 \%$.

The soil of Uladovo-Lyulinetska RBS is a leached black soil, which has the following agrochemical indices $0-30 \mathrm{~cm}$ soil layer: the content of humus by Tyurin $-4.1 \%$, total nitrogen $-0.28 \%$, mobile phosphorus $\left(\mathrm{P}_{2} \mathrm{O}_{5}\right)$ and potassium $\left(\mathrm{K}_{2} \mathrm{O}\right)$ by Chirikov - respectively $156-160$ and $78-82 \mathrm{mg} / \mathrm{kg}$ of soil, pHsalt -5.3 , hydrolytic acidity by Kappen -3.9 mg-equiv. / $100 \mathrm{~g}$ of soil.

The crop drilling area $-100 \mathrm{~m}^{2}$, the accounting area $-50 \mathrm{~m}^{2}$, the repetition is four times. Defecate contained: $\mathrm{CaCO}_{3}+\mathrm{MgCO}_{3}-84.5 \%$, organic matter - 13-15\%, nitrogen - 0.6-0.8\%, phosphorus $\left(\mathrm{P}_{2} \mathrm{O}_{5}\right)$ $0.7-0.9 \%$, potassium $\left(\mathrm{K}_{2} \mathrm{O}\right)-0.7-1.0 \%$. The ameliorant was applied in the autumn under the stalk cultivation with further plowing into the soil on the background of organic-mineral fertilizers in doses calculated on the basis of the hydrolytic acidity of the soil in accordance with the experimental scheme. 
Agrotechnology of sugar beet cultivation is commonly used for the Forest-Steppe Zone, hydride Yaltushkivsky 72.

For physic-chemical and agrochemical analyzes, sampling of soil and plants was carried out and phenological observations were made on the growth and development of plants in compliance with the research method of sugar beet plants [15].

Research results. Among the important modern issues and problems of agriculture solving and implementation of amelioration measures in increasing the stability of the soil and soil base saturation complex. One of the factors of preservation and reproduction of acid soil fertility is the improvement of their physical and chemical properties through the application of chemical and natural ameliorants.

The results of field research conducted during 2016-2018 in the conditions of the Right Bank and Central Forest-Steppe on gray forest weakly acidic soil and leached black soil showed that the application of defecate in grain-row crops rotation using the technology of layered application in the autumn under stubble cultivation with further lowing into the soil stimulated the stabilization of soil base saturation complex of acidified soils.

Studies conducted on the Yaltushky RBS on gray forest weakly-eroded rough-dust mediumloamy texture weakly acidic soils indicate that the use of ameliorant in the form of defecates over the background of organic-mineral fertilizers greatly improves the physical and chemical properties of the soil.

By our research results, $\mathrm{CaCO}_{3}$ which contains defecates significantly impacted on the absorption complex of the soil.

When determine the changes in the physical-chemical properties of gray forest soil, it has been defined that the application of ameliorant significantly influenced both the index of pHsalt and hydrolytic acidity in the arable and sub-arable layers of the soil under the technology of layered ameliorant application - dose for stubble cultivation in autumn + dose in pre-sowing cultivation in spring over the background (straw $5 \mathrm{t} /$ ha under stubble cultivation $+\mathrm{N}_{120} \mathrm{P}_{120} \mathrm{~K}_{120}$ - under plowing) (table 1, figure 1).

Thus, the indicator of pHsalt in the control variant was 5.7, which meets near neutral reaction of soil solution, but on the background of fertilizers application (straw $5 \mathrm{t} /$ ha under stubble cultivation + $\mathrm{N}_{120} \mathrm{P}_{120} \mathrm{~K}_{120}$ under the plowing) - 5.6. The use of ameliorant on the background of fertilizers application with doses 0,$5 ; 1.0$ of norms of $\mathrm{CaCO}_{3}$ by hydrolytic acidity $(3.0 ; 6.0 \mathrm{t} /$ ha in physical weight) contributed to an increase of the index of pHsalt till 6.2 and 6.8 , reciprocally, approaching to neutral and close to the neutral soil acidity. The application of defecate in 1.5 norms of $\mathrm{CaCO} 3$ by hydrolytic acidity $(9.0 \mathrm{t} / \mathrm{ha}$ in physical weight) increased the index of pHsalt up to 7.2 , meeting neutral and slightly alkaline acidity level.

In the control without defecate, the hydrolytic acidity of the soil was $2.30 \mathrm{mg}$-equiv. / $100 \mathrm{~g}$ of soil, but on the background of fertilizers application (straw $5 \mathrm{t} /$ ha under stubble cultivation $+\mathrm{N}_{120} \mathrm{P}_{120} \mathrm{~K}_{120}$ under the plowing) $-2.60 \mathrm{mg}$-equiv. / $100 \mathrm{~g}$ of soil.

The maximum neutralization of soil acidity was achieved by applying defecate in 1.5 dose according to the index of soil hydrolytic acidity $(9 \mathrm{t} / \mathrm{ha}$ in physical weight) on the fond of organic-mineral fertilizers.

In this variant of the experiment, the hydrolytic acidity of the gray forest weakly acidic soil decreased significantly and amounted to $0.42 \mathrm{mg}$-equiv. / $100 \mathrm{~g}$ of soil.

Carrying out reclamation measures contributed to the stabilization of the base saturation complex of the soil. The replacement of hydrogen ions for calcium in the absorbing complex of gray forest weakly acidic soil under the influence of defecate has greatly contributed to the increase in the sum of absorbed alkaline ions and the degree of soil base saturation that was in proportion to the amount of the applied ameliorant. 
Table 1. Influence of the application of defecate on the stabilization of the acid-alkaline balance of gray forest weakly acidic soil under the biologization of sugar beet growing, Yaltushky RBS (average for 2016-2018 years)

The application over the background of fertilizers 0,5 and 1,0 doses of $\mathrm{CaCO}_{3}$ by hydrolytic

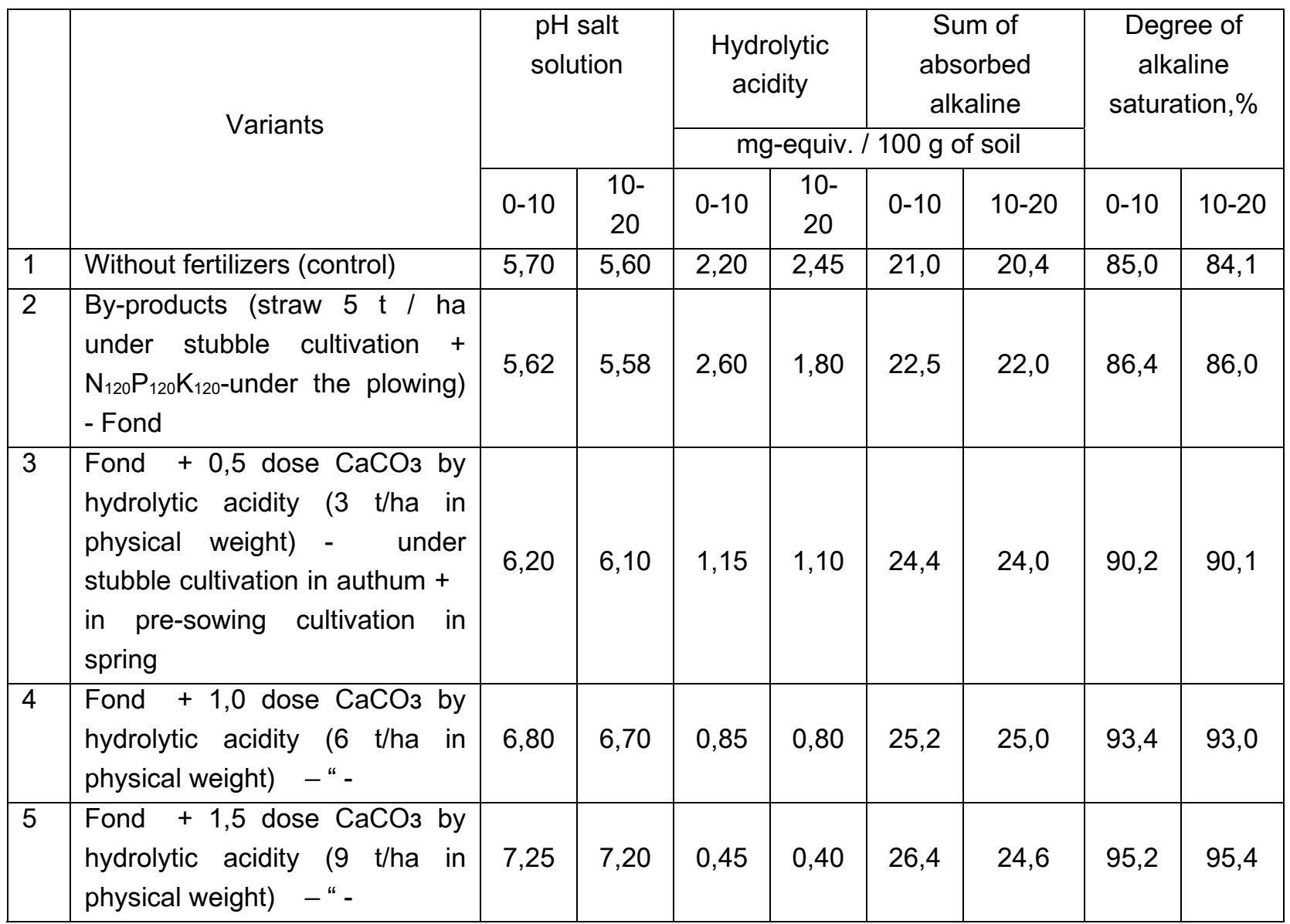

acidity (3,0-6,0 $\mathrm{t} /$ ha in physical weight) - reduced the index of hydrolytic acidity of the soil to 1,12 and $0.82 \mathrm{mg}$ equivalents per $100 \mathrm{~g}$ soil, reciprocally.

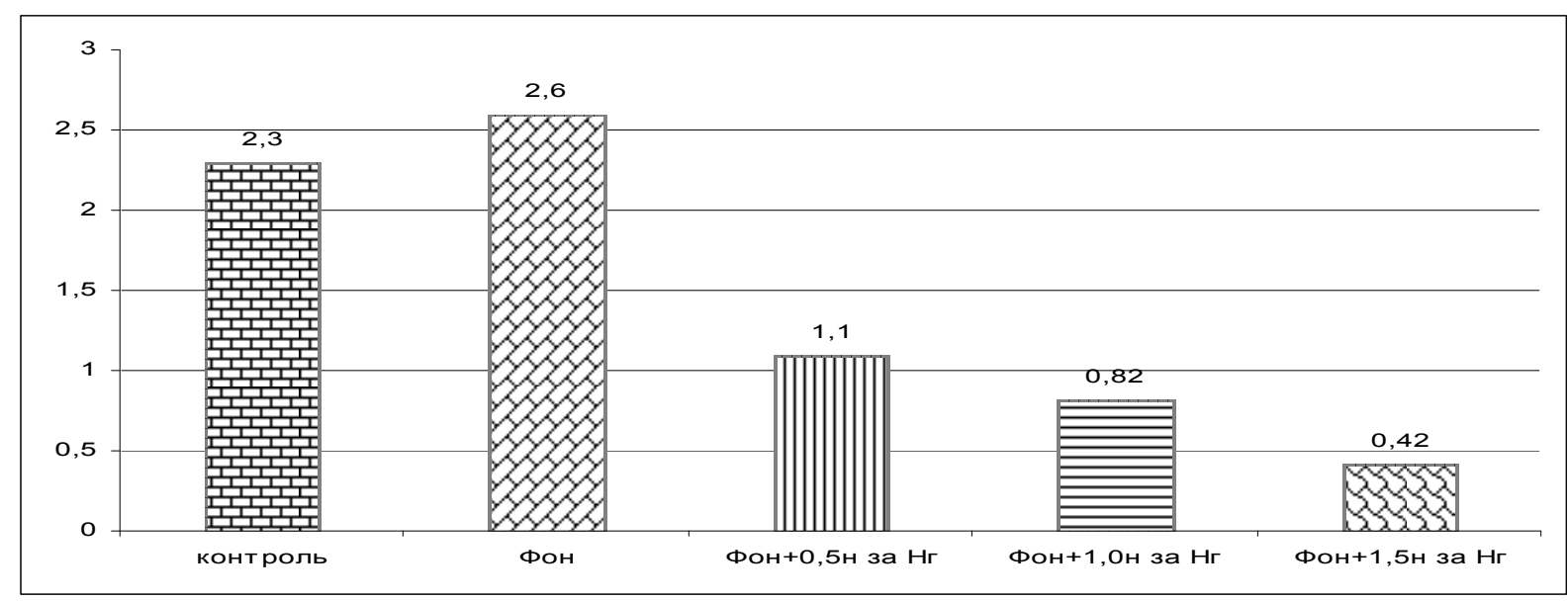

Figure. 1. Hydrolytic acidity of gray forest low-acidic soil under the technology of layered application of defecate for the biologization of sugar beet cultivation (layer 0-30 cm), mg-equiv. / $100 \mathrm{~g}$ of soil, Yaltushky (average for 2016-2018 years) 
Thus, in the control variant of the experiment the sum of absorbed alkaline ions was $20.7 \mathrm{mg}$ equiv. / $100 \mathrm{~g}$ of soil, and the degree of soil base saturation was $84.5 \%$, while in the fond variant: mgequiv. / $100 \mathrm{~g}$ of soil and $86.2 \%$, reciprocally. Application of ameliorant over the fond of organic-mineral fertilizers in 0,5 and 1.0 doses of $\mathrm{CaCO}_{3}$ by indicator of soil hydrolytic acidity contributed to an increase the sum of absorbed alkaline ions - reciprocally to 24,2 and $25,1 \mathrm{mg}$-equiv. / $100 \mathrm{~g}$ of soil with an increase in the degree of soil base saturation up to 90.1 and $93.2 \%$. The application of ameliorant in 1.5 dose of $\mathrm{CaCO} 3$ by hydrolytic acidity ( $9 \mathrm{t} / \mathrm{ha}$ in physical weight) increased these indexes reciprocally to $25.7 \mathrm{mg}$-equiv. / $100 \mathrm{~g}$ of soil and $95.3 \%$.

Consequently, the results of studies on gray forest weakly acidic soil indicate that the action of ameliorant in the form of defecate over the fond of organic-mineral fertilizers under the biologization of sugar beet cultivation contributes to the stabilization of the acid-alkaline balance of the investigated soil.

Studies conducted in the Uladovo-Lyulinetska RBS on leached low-acidic black soil indicate the efficiency of the use of the dried purified from the impurities defecate produced by new technology. The ameliorant applied in autumn under stubble cultivation with subsequent plowing on the fond of organicmineral fertilizers (straw $5 \mathrm{t} /$ ha $+\mathrm{N}_{90} \mathrm{P}_{60} \mathrm{~K}_{90}$ ) greatly improves the physical and chemical properties of the soil.

Application of defecate, obtained by the new technology, in grain-row crops rotation on slightly acidic leached black soil in the doses calculated by the index of hydrolytic acidity indicates the stabilization of the acid-alkaline balance of the investigated soil (table 2, figure 2).

So, the index of pHsalt in the control variant was 5.5 , which corresponds to a slightly acidic soil environment, as well as in the fond variant -6.0 .

Applying ameliorant for plowing in doses 0.5 and 1.0 (2.5 and $5.0 \mathrm{t} /$ ha in physical weight) contributed to an increase in the pHsalt index - reciprocally till 6.2 and 6.4, that meets neutral and close to neutral degree of acidity. The applying defecate in 1.5 dose increased the pHsalt score to 6.9 that corresponds to the neutral degree of acidity.

With regard to the hydrolytic acidity of leached weakly acidic black soil, its significant decrease was observed in comparison with the control variant under the action of defecate applied for plowing on the fond of organic-mineral fertilizers.

In the control variant this indicator was 3.70 mg-equiv. / $100 \mathrm{~g}$ of soil, as well as in the fond variant $-3.10 \mathrm{mg}$-equiv. / $100 \mathrm{~g}$ of soil.

Table 2. Influence of doses and way of defecate application on stabilization of acid-alkaline balance of leached weakly acidic black soil, Uladovo-Liulinetska RBS (average for 2016-2018 years)

\begin{tabular}{|c|c|c|c|c|c|c|c|}
\hline \multirow[b]{2}{*}{$\begin{array}{l}\text { № } \\
\text { var. }\end{array}$} & \multirow[b]{2}{*}{ Variant } & \multirow{2}{*}{$\begin{array}{l}\text { Soil } \\
\text { layer, } \\
\mathrm{cm}\end{array}$} & \multirow[b]{2}{*}{$\begin{array}{l}\mathrm{pH} \\
\text { salt }\end{array}$} & \multirow{2}{*}{$\begin{array}{l}\text { Hydrolytic } \\
\text { acidity, } \\
\text { mg-equiv. } \\
/ 100 \mathrm{~g} \text { of } \\
\text { soil }\end{array}$} & \multirow{2}{*}{$\begin{array}{l}\text { Sum, mg- } \\
\text { equiv. / } \\
100 \mathrm{~g} \text { of } \\
\text { soil }\end{array}$} & $\mathrm{CaO}$ & $\mathrm{MgO}$ \\
\hline & & & & & & \multicolumn{2}{|c|}{$\begin{array}{c}\text { mg-equiv. / } 100 \mathrm{~g} \text { of } \\
\text { soil }\end{array}$} \\
\hline \multirow{2}{*}{1} & \multirow{2}{*}{$\begin{array}{l}\text { Without fertilizers } \\
\text { (control) }\end{array}$} & $0-30$ & 5,55 & 3,70 & 23,5 & 160,5 & 16,5 \\
\hline & & $30-50$ & 5,56 & 0,85 & 42,5 & 165,2 & 13,2 \\
\hline \multirow[b]{2}{*}{2} & \multirow{2}{*}{$\begin{array}{l}\text { By-products (straw } 5 \mathrm{t} / \\
\text { ha under stubble } \\
\text { cultivation }+\mathrm{N}_{90} \mathrm{P}_{60} \mathrm{~K}_{90}- \\
\text { under the plowing) - } \\
\text { Fond }\end{array}$} & $0-30$ & 6,00 & 3,10 & 26,0 & 162,5 & 17,0 \\
\hline & & $30-50$ & 5,95 & 1,10 & 30,55 & 170,1 & 15,3 \\
\hline \multirow[b]{2}{*}{3} & \multirow{2}{*}{$\begin{array}{l}\text { Fond }+0,5 \text { dose } \mathrm{CaCO}_{3} \\
\text { by hydrolytic acidity }(2,5 \\
\text { t/ha in physical weight) } \\
\text { under plowing }\end{array}$} & $0-30$ & 6,26 & 2,95 & 27,0 & 163,4 & 17,5 \\
\hline & & $30-50$ & 6,36 & 0,60 & 42,5 & 164,2 & 16,0 \\
\hline
\end{tabular}




\begin{tabular}{|c|l|c|c|c|c|c|c|}
\hline & \begin{tabular}{l} 
Fond + 1,0 dose CaCO3 \\
by hydrolytic acidity (5 \\
\cline { 5 - 8 } \\
t/ha in physical weight) \\
under plowing
\end{tabular} & $30-50$ & 7,01 & 1,12 & 39,6 & 170,2 & 22,0 \\
\hline \multirow{2}{*}{5} & $\begin{array}{l}\text { Fond + 1,5 dose CaCO3 } \\
\text { by hydrolytic acidity (7,5 } \\
\text { t/ha in physical weight) } \\
\text { under plowing }\end{array}$ & $0-30$ & 6,88 & 1,50 & 28,5 & 175,0 & 24,0 \\
\cline { 5 - 8 } & & 6,89 & 0,70 & 44,2 & 180,3 & 18,2 \\
\hline
\end{tabular}

By the application of ameliorant in 0,5 dose $\mathrm{CaCO}_{3}$ according to hydrolytic acidity $(2,5 \mathrm{t} /$ ha in physical weight) - under the plow the hydrolytic acidity of the soil decreased to a level of $2.95 \mathrm{mg}$ ek per $100 \mathrm{~g}$ of soil, and the application of 1.0 dose $\mathrm{CaCO}_{3}$ per hydrolytic acidity $(5.0 \mathrm{t} / \mathrm{ha}$ in physical weight) the hydrolytic acidity of the soil was 2.70 mg-equiv. / $100 \mathrm{~g}$ of soil.

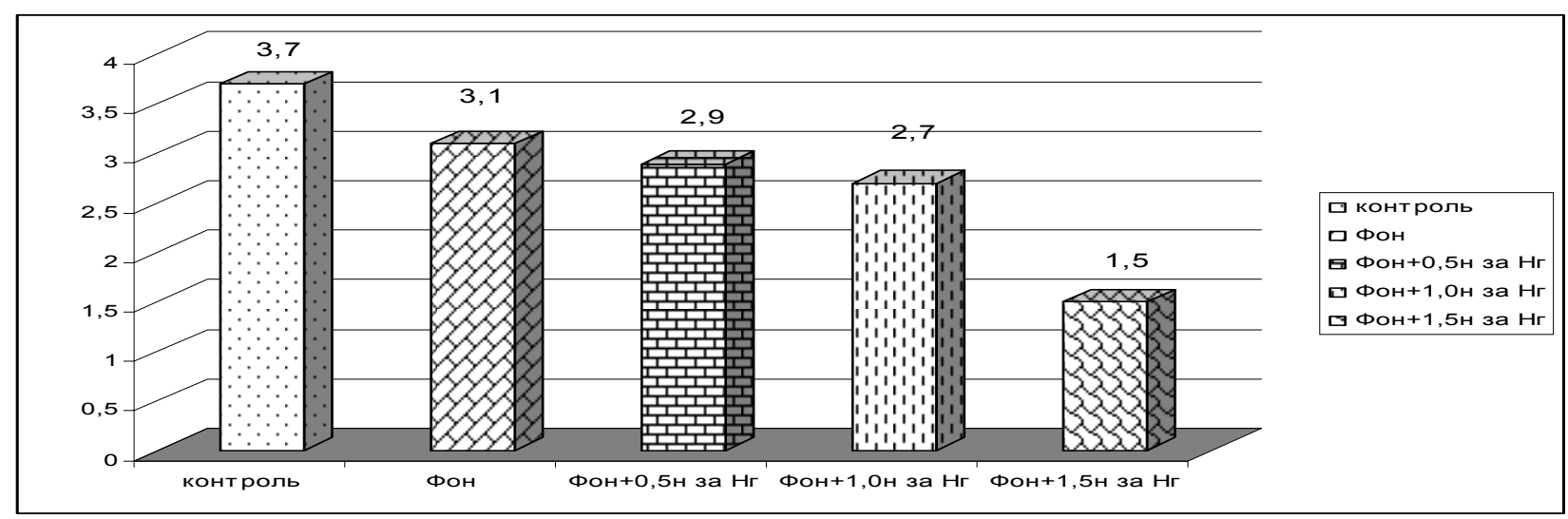

Figure. 2. Hydrolytic acidity of leached weakly acidic black soil under defecate application for plowing by biologization of sugar beet growing (layer 0-30 cm) mg-equiv. / $100 \mathrm{~g}$ of soil, Uladovo-Liulinetska RBS (average for 2016-2018 years)

For the application of 1.5 dose $\mathrm{CaCO}_{3}$ per hydrolytic acidity $(7.5 \mathrm{t} /$ ha in physical weight) - the hydrolytic acidity of the soil decreased to $1.50 \mathrm{mg}$-equiv. / $100 \mathrm{~g}$ of soil.

When applying ameliorant, along with the decrease in the hydrolytic acidity of the soil, an increase the sum absorbed alkaline ions and the degree of base saturation is determined.

Thus, in the control variant of the experiment, the sum of absorbed alkaline ions was $23.5 \mathrm{mg}$ equiv. / $100 \mathrm{~g}$ of soil. Application of ameliorant on the fond of organic-mineral fertilizers in 0,5 and 1.0 doses $\mathrm{CaCO}_{3}$ per hydrolytic acidity (2.5 and $5.0 \mathrm{t} /$ ha in physical weight) contributed to an increase the sum of absorbed alkaline ions - reciprocally to 27.0 and $26.8 \mathrm{mg}$-equiv. / $100 \mathrm{~g}$ of soil. The applying ameliorant in 1.5 dose of $\mathrm{CaCO}_{3}$ per hydrolytic acidity $(7.5 \mathrm{t} /$ ha in physical weight) increased this indicator to $28.5 \mathrm{mg}$-equiv. / $100 \mathrm{~g}$ of soil.

The obtained research results indicate the positive effect of reclamation on the content of mobile forms of calcium and magnesium. Thus, in the control variant of the trial, the indexes of the content of these compounds were reciprocally 160.5 and $16.5 \mathrm{mg}$-equiv. / $100 \mathrm{~g}$ of soil. By the application of defecate 1,5 dose of $\mathrm{CaCO}_{3}$ per hydrolytic acidity $(7,5 \mathrm{t} /$ ha in physical weight), the content of mobile compounds of calcium reached $175.0 \mathrm{mg}$-equiv. / $100 \mathrm{~g}$ of soil, and mobile compounds of magnesium $24.0 \mathrm{mg}$-equiv. / $100 \mathrm{~g}$ of soil.

Thus, the application of an ameliorant under the biologization of sugar beet cultivation contributes to the stabilization of the soil absorption complex with the improvement of the physical and chemical properties of the soils under study. 


\section{Conclusions}

Thus, according to the research results carried out within 2016-2018 in the conditions of the Right Bank and Central Forest-Steppe of Ukraine, one can state:

1. For the application of defecate on gray forest weakly acidic soil based on the layered applying ameliorant in 0,5 and 1.0 doses $\mathrm{CaCO}_{3}$ per hydrolytic acidity $(3.0$ and $6.0 \mathrm{t} /$ ha in physical weight) on the fond of organic-mineral fertilizers (straw $5 \mathrm{t} /$ ha for stubble cultivation $+\mathrm{N}_{120} \mathrm{P}_{120} \mathrm{~K}_{120}$ under plowing), a significant increase in the index of pHsalt - reciprocally to 6,2 and 6.8 with a decrease in hydrolytic acidity - to 1.12 and $0.82 \mathrm{mg}$-equiv. / $100 \mathrm{~g}$ of soil and increasing the sum of absorbed alkaline ions - to 24.2 and $25.1 \mathrm{mg}$-equiv. / $100 \mathrm{~g}$ of soil and degree of bases saturation - up to 90.1 and $93.2 \%$ was determined; while the indicators in the control variant: 5.7, 2.3 and 20.7 mg-equiv. / $100 \mathrm{~g}$ of soil and $84.5 \%$, respectively.

2. The most influence on the soil absorption complex of gray forest weakly acidic soil was observed under 1.5 dose of $\mathrm{CaCO}_{3}$ per hydrolytic acidity $(9,0 \mathrm{t} /$ ha in physical weight). Herewith, the maximum neutralization of soil acidity is achieved: the index of pHsalt of the soil solution increased to 7.2 , the hydrolytic acidity of the soil decreased to $0.42 \mathrm{mg}$-equiv. / $100 \mathrm{~g}$ of soil with an increase in the sum of absorbed alkaline ions up to $25.7 \mathrm{mg}$-equiv. / $100 \mathrm{~g}$ of soil and degree of soil base saturation to $95.3 \%$.

3. Application of defecate in grain-row crops rotation on leached low-acidic black soil led to an improvement of the physical and chemical properties of the soil. Applying ameliorant in 0.5 and 1.0 doses $\mathrm{CaCO}_{3}$ per hydrolytic acidity (3.0 and $6.0 \mathrm{t} /$ ha in physical weight) on the fond of organic-mineral fertilizers (straw $5 \mathrm{t} /$ ha for cultivation $+\mathrm{N}_{90} \mathrm{P}_{60} \mathrm{~K}_{90}$ under plowing) significantly increased the pHsalt of soil solution reciprocally to 6,2 and 6,4 with a decrease in hydrolytic acidity - up to 2,95 and 2,70 mg-equiv. I $100 \mathrm{~g}$ of soil; for indicators in the control variant - respectively 5,5 and 3,70 mg-equiv. / $100 \mathrm{~g}$ of soil.

4. When applying ameliorant on leached weakly acid black soil in 1.5 dose per hydrolytic acidity ( $7,5 \mathrm{t} / \mathrm{ha}$ in physical weight), an increase in the index of pHsalt was determined to 6.9 , which corresponds to the neutral degree of soil acidity. By the mentioned dose of ameliorant, the hydrolytic acidity of the soil decreased to $1.50 \mathrm{mg}$-equiv. / $100 \mathrm{~g}$ of soil with an increase in the sum of absorbed alkaline ions - up to $28.5 \mathrm{mg}$-equiv. / $100 \mathrm{~g}$ of soil. The content of mobile compounds of calcium (CaO) increased to 175.0 mg-equiv. / $\mathrm{kg}$ of soil with an increase in magnesium (MgO) mobile compounds up to $24.0 \mathrm{mg}$-equiv. / kg of soil.

\section{Bibliography}

1. Witter B., Kolbe G. Analyse des erreichten standes in der kalkung. Falduirtschaft, 1973. 10., pp. 468-471.

2. Farina M.P.W., Channon P. Acid-subsoil amelioration.1. A comparison of several mechanical procedures. Soil Sci. Soc. Am.J., 1988, N. 52, P. 169.

3. Farina M.P.W., Channon P. Acid-subsoil amelioration.II.Gypsum effects on growth and subsoil chemical properties. Soil Sci. Soc. Am.J., 1988, N. 52, pp. 175.

4. Sumner M.E., Fey M.V., Farina M.P.W. (1987) Amelioration of acid subsoils with phosphogypsum. Proc. 2nh Int. Symp. Phosphogypsum, pp. 41. University of Miami, Florida.

5. Kirpichnikov N.A., Glazunova N.M. (1986) Priminenie povyshchennykh doz izvesti s tselyu ekonomii fosfornykh udobreniy $v$ usloviyakh tsentralnykh rayonov nechernozemnoy zony RSFSR [The use of increased doses of lime in order to save phosphorus fertilizers in the central regions of the nonchernozem zone of the RSFSR]. Byulleten Instituta udobreniy $i$ agropochvovedeniya im. D.N. Pryanishnikova (VIUA) [Bulletin of the Institute of Fertilizers and Agricultural Soil D.N. Pryanishnikova]. Moscow. № 78. pp. 28. [in Russian].

6. Knashis V.Yu. (1985) Effektivnost izvestkovaniya pochv Litovskoy SSR [The liming efficiency of soils of the Lithuanian SSR] Voprosy genezisa i plodorodiya pochv Litovskoy SSR [Issues of soil genesis and fertility of the Lithuanian SSR]. pp. 149-159. [in Russian]. 
7. Zaryshniak A.S., Tsvei Ya.P., Ivanina V.V. (2015) Optymizatsiia udobrennia ta rodiuchosti hruntu $v$ sivozminakh [Optimization of fertilizer and soil fertility in crop rotations in Kyiv]. Ahrarna nauka [Agrarian Science]. pp. 207. [in Ukrainian].

8. Ivanina V.V. (2016) Biolohizatsiia udobrennia kultur u sivozminakh: monohrafiia [Biologization of crop fertilizers in crop rotations: monograph] Kyiv: TsP «Kompryt», pp. 328. [in Ukrainian].

9. Derevyagin V.A., Popov P.V. (1989) Organicheskie udobreniya $v$ biologizatsii zemledeliya [Organic fertilizers in the biologization of agriculture]. Khimizatsiya selskogo khozyaystva [Chemicalization of agriculture]. № 10. pp. 33-35. [in Russian].

10. Taskina V.M. (1988) Soloma, kak udobrenie na polyakh chernogo para "Sibirskiy vestnik selskokhozyaystvennoy nauki" [Straw as fertilizer in the fields of black steam "Siberian Bulletin of Agricultural Science"], № 4. pp. 23-25. [in Russian].

11. Zubenko V.F., Ivashchenko A.A., Sabluk V.T., Zarishnyak A.S., Tsvey Ya.P. (2005) Sveklovodstvo. Problemy intensifikatsii i resursosberezheniya [Beet farming. Problems of intensification and resource conservation]. NPP OOO «Alfa-steviya LTD», pp. 152-177. [in Russian].

12. Barshteyn L.A., Shkaredniy I.S., Yakimenko V.M. (1996) Pitanie i produktivnost korneplodov [Nutrition and productivity of root crops]. Sakharnaya svekla [Sugar beet]. № 9. pp. 16-17. [in Russian].

13. Drahan M.I., Hamalei V.I., Liubych V.M. (2009) Ahrehatnyi sklad siroho lisovoho hruntu za riznykh ahrotekhnolohichnykh zakhodiv [Aggregate composition of gray forest soil under different agrotechnological measures]. Visnyk ahrarnoi nauky [Bulletin of agrarian science]. № 2. pp. 11-16. [in Ukrainian].

14. Sinchenko V.M., Pyrkin V.I. (2013) Upravlinnia protsesamy bioadaptyvnoi tekhnolohii vyrobnytstva tsukrovykh buriakiv [Process control of bioadaptive technology of sugar beet production]. Tsukrovi buriaky [Sugar beet]. № 3(93) pp. 6-13. [in Ukrainian].

15. Metodika issledovaniy po sakharnoy svekle [Research methodology for sugar beets]. Kiev: VNIS. 292. [in Russian]. 